\title{
Seasonally varying importance of abiotic and biotic factors in marsh-pond fish communities
}

\author{
Craig A. Layman*, David E. Smith, James Devin Herod
}

Department of Environmental Sciences, University of Virginia, Charlottesville, Virginia 22903, USA

\begin{abstract}
A series of field and laboratory experiments examined the factors that control fishassemblage structure in barrier islands ponds on the Eastern Shore of Virginia. We investigated why surf-zone fishes, which are introduced to the island ponds during periodic wash-over events, are unable to persist for extended periods. We simulated over-wash events by collecting fishes from the shallow surf-zone and introducing them into $0.56 \mathrm{~m}^{2}$ field enclosures. During summer months, surfzone fishes typically died within $24 \mathrm{~h}$. Levels of dissolved oxygen and temperature frequently exceeded the tolerance limits of the surf-zone fishes (demonstrated in a series of laboratory experiments), suggesting that these variables were responsible for fish mortality. In non-summer months, when dissolved oxygen and temperature stresses were ameliorated, surf-zone fishes could survive for months in the ponds. We conducted field-enclosure experiments at 3 fish densities in order to evaluate the survival and condition of a common surf-zone fish, Membras martinica (the rough silverside): (1) $8 \mathrm{M}$. martinica (14 fish $\mathrm{m}^{-2}$ ), (2) $16 \mathrm{M}$. martinica (28 fish $\mathrm{m}^{-2}$ ), and (3) $8 \mathrm{M}$. martinica +8 Fundulus heteroclitus ( 28 fish $\mathrm{m}^{-2}$ ). After approximately 1 mo during the spring, fall and winter, survival and condition of fishes in Treatments 2 and 3 were significantly reduced, suggesting that biological interactions were an important cause of surf-zone fish mortality. A temporal environmental stress gradient may result in seasonally varying importance of abiotic and biotic structuring factors.
\end{abstract}

KEY WORDS: Marsh pond · Fish · Competition · Seasonal · Dissolved oxygen · Community structure · Barrier Island · Virginia

Resale or republication not permitted without written consent of the publisher

\section{INTRODUCTION}

The relative importance of abiotic and biotic factors in structuring faunal communities has received much attention in recent years. One approach for evaluating community structure has been to assess the relative importance of abiotic factors, competition, and predation based on a gradient of environmental stress (Connell 1975, Menge 1976, Peckarsky 1983, Menge \& Sutherland 1987, Huston 1994, Leonard et al. 1998). Menge \& Sutherland (1987) proposed a conceptual framework in which the relative importance of biotic factors increases as environmental stress decreases.

*Present address: Department of Wildlife and Fisheries Sciences, Texas A \& M University, 210 Nagle Hall, College Station, Texas 77843-2258, USA. E-mail: cal1634@unix.tamu.edu
Empirical evidence of communities organized in this fashion has been provided in rocky intertidal communities (Dayton 1971, Menge 1976, 1978a,b, 1983, Connell 1985, Menge \& Farrell 1989, Menge et al. 1993) and stream benthic invertebrate associations (Lancaster 1990, 1996, Peckarsky et al. 1990, Hansen et al. 1991).

In these studies, the relative importance of community-structuring mechanisms is predicted based on spatial variation in environmental stress. For example, this spatial gradient is based on degree of wave exposure in rocky intertidal systems (Menge \& Farrell 1989). In this study, we present evidence that a temporally defined gradient of environmental stress, instead of the more common spatial gradient, may be useful in evaluating the predictions made by Menge \& Sutherland (1987). Using this temporal context, we evaluated 
the importance of abiotic and biotic factors in structuring fish communities of barrier island marsh ponds on the Eastern Shore of Virginia.

In such marsh ponds, Poulin \& Fitzgerald (1989) and Dunson et al. (1993) found that abiotic factors play the predominant role in structuring fish communities. In contrast, Weisberg (1986) and Dunson \& Rowe (1996) suggested that biotic interactions may be more important. Combining these approaches, Rowe \& Dunson (1995) showed that both abiotic (salinity) and biotic (competition) factors influence the growth and survival of 3 common salt-marsh pool residents: Cyprinodon variegatus (sheepshead minnow), Lucania parva (rainwater killifish), and Menidia beryllina (inland silverside). These studies present evidence that a variety of factors are likely to contribute to patterns of community structure in marsh ponds, although none of the studies specifically define the circumstances in which abiotic or biotic factors are more important.

Previous studies of barrier island ponds are primarily descriptive and do not elucidate the factors that shape fish communities. Studies on Horn Island, Mississippi (Franks 1970, Ross \& Doherty 1994) and the Outer Banks, North Carolina (Schwartz 1988, Schwartz et al. 1990a,b), have found that communities are dominated by relatively few species, primarily poeciliids, cyprinodontids, fundulids, and atherinids. Ross \& Doherty (1994) found that no combination of physiochemical variables could be used to explain fish assemblage patterns, although they were able to discern trends in community composition. They identify 2 groups of fishes based on source of colonization, 'marsh' fishes and 'surf-zone' fishes, and found that ponds dominated by surf-zone species shifted over time to a marsh fish dominated community. The surf-zone species were assumed to be unable to tolerate the physiological demands in the ponds.

The present study examined fish assemblage structure in near-shore marsh ponds on the Virginia barrier islands. These ponds are typically dominated by resident marsh species, primarily Fundulus heteroclitus (mummichog) and Cyprinodon variegatus, despite over-wash events from the ocean surf-zone that bring influxes of other species. As was observed by Ross \& Doherty (1994), surf-zone fishes are unable to persist in the ponds for extended periods of time. This study describes why these surf fishes are unable to persist in ponds and provides empirical evidence for the structuring factors operating within these ponds. The following hypotheses were tested: (1) abiotic factors are the primary cause of surf-zone fish mortality during the summer, and (2) biotic interactions contribute to surf-zone fish mortality in other seasons of the year when the environmental stress of the ponds is ameliorated.

\section{METHODS}

Site description. The Virginia Coast Reserve LongTerm Ecological Research Site (VCR-LTER) includes a $100 \mathrm{~km}$ stretch of barrier islands, mainland marsh, and associated lagoons, along the Virginia portion of the Delmarva Peninsula (Fig. 1). The experiments were conducted on Hog Island, which is approximately $11 \mathrm{~km}$ in length and up to $3 \mathrm{~km}$ wide. There are numerous shallow (usually $<1 \mathrm{~m}$ ) ponds on the island that range in area from $<1$ to $>150000 \mathrm{~m}^{2}$. The ponds investigated in this study were primarily located on the ocean-side (North, South, Y, West and Back Ponds) or middle (Low, Shallow and Middle Island Pond) of Hog Island (see Fig. 1). All ponds included in this study were located in typical high-marsh terrain in which the primary vegetation was salt marsh hay Spartina patens. Salinities commonly varied from 10 to $40 \mathrm{ppt}$, although more extreme levels have been observed. The ponds were characterized by abundant submerged aquatic vegetation including numerous filamentous algae species, as well as other species of both micro- and macro-algae. Widgeon grass Ruppia maritima was common in many of the ponds. Substrates ranged from thick, organically rich mud to fine sand. In general, ponds contain more water during the winter, spring, and late fall, but were dry throughout the summer (see multi-year database of VCR-LTER: http:// atlantic.evsc.virginia.edu/data.html\#physical). During high tides, ponds are periodically over-washed by the ocean or by adjacent back bays, trapping intertidal fishes in the ponds (Layman pers. obs.).

Pond surveys. The experimental densities were based on densities of fishes in ponds on the Virginia barrier islands. Table 1 gives fish densities for all fishes and densities of the rough silverside Membras martinica (the species that was used in the experiments described below) in the 2 most extensively sampled ponds on Hog Island, North and South Ponds. Densities were estimated using 2 nets: (1) an 8-m-long seine, $1.5 \mathrm{~m}$ deep, with a $1 \mathrm{~m}^{2} \mathrm{bag}$ and $0.48 \mathrm{~cm}$ mesh, and (2) a 4 -m-long seine, $1.5 \mathrm{~m}$ deep, with a $1 \mathrm{~m}^{2}$ bag and $1 \mathrm{~mm}^{2}$ mesh. Fish densities fluctuated substantially among, as well as within, months due to precipitation, overwash, dynamic island geomorphology and the immigration, emigration, birth and death of the fishes. Densities of fishes also varied substantially among pond microhabitats. Furthermore, collection efficiency probably varied due to pond shape and size, as well as the composition of the fish assemblage (Allen et al. 1995). The densities reported here are similar to those for marsh ponds elsewhere (Whoriskey \& Fitzgerald 1987, Loftus \& Eklund 1994, Rowe \& Dunson 1995, Layman 1999). The most accurate density estimates were made in the summer and early fall, when water 


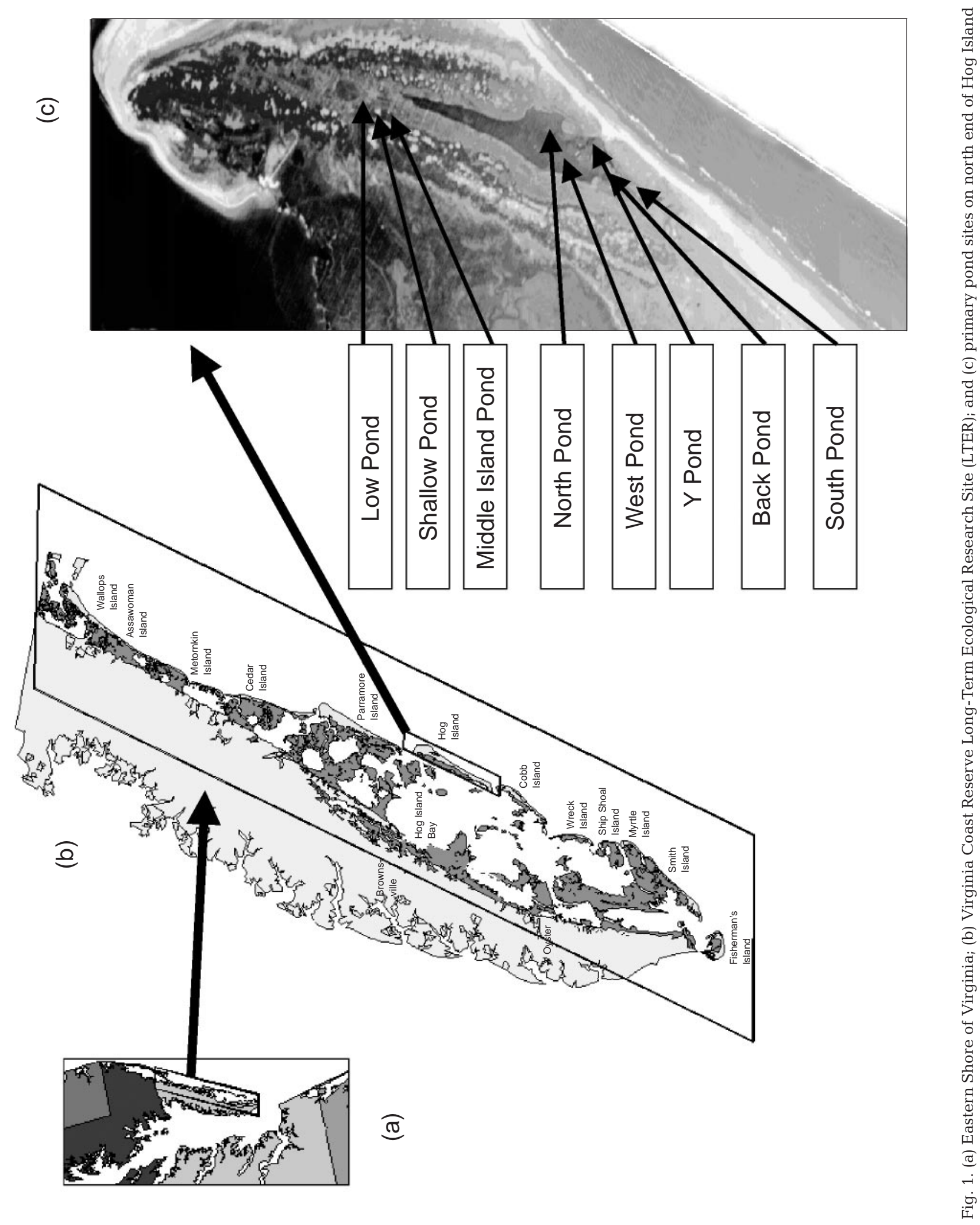


Table 1. Total fish densities and densities of Membras martinica in 2 ponds on Hog Island, Virginia, as estimated by seining. All densities are expressed as number of fish $\mathrm{m}^{-2}( \pm 1 \mathrm{SD})$

\begin{tabular}{|c|c|c|c|c|}
\hline \multirow[t]{2}{*}{ Month } & \multicolumn{2}{|c|}{ North Pond } & \multicolumn{2}{|c|}{ South Pond } \\
\hline & $\begin{array}{c}\text { Total } \\
\text { density }\end{array}$ & $\begin{array}{l}\text { M. martinica } \\
\text { density }\end{array}$ & $\begin{array}{l}\text { Total } \\
\text { density }\end{array}$ & $\begin{array}{l}\text { M. martinica } \\
\text { density }\end{array}$ \\
\hline \multicolumn{5}{|l|}{1997} \\
\hline Apr & $3.2(2.6)$ & $1.2(1.3)$ & $5.6(3.7)$ & $1.2(2.1)$ \\
\hline May & $32.1(24.2)$ & $26.7(19.8)$ & $57.4(18.2)$ & $38.9(19.3)$ \\
\hline Jun & $112.3(36.0)$ & $0.7(0.7)$ & $156.2(57.1)$ & $0.0(0.0)$ \\
\hline Jul & $156.8(56.1)$ & $0.0(0.0)$ & $211.9(32.1)$ & $0.0(0.0)$ \\
\hline Aug & $12.1(4.6)$ & $0.8(0.2)$ & $0.7(0.5)$ & $0.0(0.0)$ \\
\hline Sep & $54.4(30.0)$ & $54.1(29.8)$ & $56.3(21.1)$ & $0.0(0.0)$ \\
\hline Oct & $43.9(21.1)$ & $22.1(15.1)$ & $38.2(12.9)$ & $21.1(14.8)$ \\
\hline Nov & $32.4(19.5)$ & $7.7(8.1)$ & $11.4(5.4)$ & $4.2(3.3)$ \\
\hline Dec & $13.1(5.7)$ & $2.1(4.6)$ & $16.2(11.9)$ & $10.1(7.9)$ \\
\hline \multicolumn{5}{|l|}{1998} \\
\hline Feb & $12.5(9.2)$ & $10.8(8.7)$ & $2.1(0.9)$ & $1.9(0.9)$ \\
\hline
\end{tabular}

levels were relatively low. At these times the ponds were often very small and could be completely sampled with each seine net pass, resulting in an excellent approximation of the actual fish assemblage present. Further details on fish densities and seining used to estimate these densities are found in Layman (1999).

The fish community in these island ponds was dominated by small killifish, primarily Fundulus heteroclitus and Cyprinodon variegatus. Also common in the ponds were Lucania parva and Gasterosteus aculeatus (3spine sticklebacks). Each of these 4 species can be considered 'resident' in the marsh ponds (sensu Ross \& Doherty 1984). Additionally, numerous species that are trapped in the ponds during wash-over events are common members of the pond-fish community. These 'surfzone species' (sensu Ross \& Doherty 1984) include Membras martinica (rough silverside), Mugil curema (white mullet), and Fundulus majalis (striped killifish). Additional information on the pond-fish community can be found in Layman (1999). For the purposes of this paper 'community structure' is defined as the relative abundance of the fishes in the island ponds.

General experimental protocol. Experiments were designed to simulate an actual over-wash event in which Membras martinica are introduced into the island ponds. This particular species was selected because it is the most common fish of the shallow surfzone of the Virginia Eastern Shore barrier islands (Layman 2000). Following an actual over-wash event, M. martinica are presumably subjected to varying levels of environmental stress and biotic interactions in the ponds. In order to evaluate the effects of these factors on the survival and condition of $M$. martinica, we conducted a series of enclosure experiments over several seasons. Three treatments were utilized in the ex- perimental designs: (1) control: $8 \mathrm{M}$. martinica (14 fish $\left.\mathrm{m}^{-2}\right)$; (2) intraspecific interactions: $16 \mathrm{M}$. martinica (28 fish $\left.\mathrm{m}^{-2}\right)_{i}(3)$ interspecific interactions: 8 M. martinica +8 Fundulus heteroclitus (28 fish $\mathrm{m}^{-2}$ ). F. heteroclitus was used in Treatment 3 because it is one of the most common fishes in the island ponds, and thus one of the species most likely to influence the success of $M$. martinica. These experimental densities were well within actual pond-fish densities on the Virginia barrier islands (Table 1). The experiment was conducted throughout the year in order to incorporate natural seasonal variability in environmental stress.

All experiments were conducted in enclosures constructed with a square, welded, rebar frame $(0.95 \mathrm{~mm}$ diameter rebar $)$ covered with $0.48 \mathrm{~cm}$ nylon mesh. Each side of the frame enclosure measured $0.75 \mathrm{~m}$, resulting in an enclosed surface area of $0.56 \mathrm{~m}^{2}$. The depth of water (although variable during the course of the experiment) was initially $60 \mathrm{~cm}$ in each enclosure. The mesh was attached to the frame with plastic cable ties at $1 \mathrm{~cm}$ increments and was pulled taut to ensure it would remain tight once placed in the water. Both the sides and the bottoms of the enclosures were covered with this nylon mesh, which allowed all small organisms and sediment to freely pass in and out of the enclosed area. Importantly, it was possible for water to move freely through the sides of the enclosures, for example, during winddriven surface water movement. Physical water-quality measurements (e.g. dissolved oxygen and temperature) were made frequently during each experiment, both day and night, to ensure that conditions inside the enclosures did not differ from those in the ponds. Even at 28 fish $\mathrm{m}^{-2}$, the highest fish density used in the experiments, dissolved oxygen and other physiochemical conditions were indistinguishable from those outside the enclosures (Layman unpubl. data). The enclosures were secured in the ponds by $10 \mathrm{~cm}$ extensions on each enclosure leg that were pressed into the substrate. In a given pond, all enclosures were separated by $1 \mathrm{~m}$. The top of each enclosure was covered with a $1.3 \mathrm{~cm}$ wire mesh top with numerous perpendicular wire extensions in order to deter birds. In summary, the enclosures kept the experimental fishes in and predators out, but allowed water, food, and all other small material to move freely in and out of the area.

Membras martinica used in the experiments were collected by pulling a seine parallel to the shore in the 
shallow ocean water $(<0.4 \mathrm{~m})$ adjacent to the beach. The fish were placed in buckets filled with seawater and the buckets were immediately covered with lids to prevent overheating. Battery-powered air pumps were used to oxygenate the water continuously. Once the bucket water temperature had adjusted to within $1^{\circ} \mathrm{C}$ of the water temperature in the ponds, the fish were introduced into the field enclosures. Fundulus heteroclitus were collected using minnow traps in the specific pond where the experiment was to take place. F. heteroclitus were placed in a separate enclosure from $M$. martinica, and both species were allowed to acclimate for $24 \mathrm{~h}$. After this period, the experiment was initiated by distributing the fishes among the enclosures according to the experimental design specific to each season (see following subsection and summary in Fig. 2).

At the end of each experiment, living fishes were counted, measured, and weighed. Two indices were used to compare fishes from the experimental treat- ments: survivability and condition. The condition of the fish was analyzed using the $K$ condition factor (see Weatherly 1972 and Everhart \& Youngs 1981 for further discussion):

$$
K=W / L^{3}
$$

where $K$ represents the condition index, $W$ the fish weight $(\mathrm{g}) \times 100$, and $L$ the fish length $(\mathrm{cm})$. For fishes of a given length, a higher $K$ generally indicates a more 'fit' fish.

Seasonal experimental design. Spring: The spring experiment was conducted from April 28 until June 10. A total of 24 enclosures were utilized, 6 in each of 4 ponds (North, South, Y, and Middle Island). Only Treatments 1 and 3 (i.e. 'control' and 'interspecific interactions') were utilized during the spring experimental design; both were replicated 3 times in each pond. During the course of the spring experiment, heavy rains and frequent tidal wash-over events raised water levels over the top of the enclosures in 3 of the 4

\begin{tabular}{|c|c|c|c|c|}
\hline Treatment 1 & Treatment 2 & Treatment 3 & \multicolumn{2}{|c|}{ Ponds } \\
\hline "Control" & $\begin{array}{l}\text { "Intraspecific } \\
\text { Interactions" }\end{array}$ & $\begin{array}{l}\text { "Interspecific } \\
\text { Interactions" }\end{array}$ & Initially Setup & Data Collected \\
\hline
\end{tabular}

Middle Island
Fall

Fig. 2. Summary of experimental sampling design. Included are ponds in which experiments were initially set up and ponds from which data were collected. Data were not collected from a given pond if fishes escaped during the experiment due to high water levels, overturned enclosures, or damage to mesh. Mm: Membras martinica; Fh: Fundulus heteroclitus 
ponds, allowing all fish to escape. Therefore, data were only collected from the 1 remaining site (Middle Island Pond). Survival was expressed as the proportion of Membras martinica surviving until the end of the experiment. The proportions were transformed by taking the arcsine of the proportion square-root in order to account for the non-normal distribution of proportional data (Zar 1996) and then compared with a Student's $t$-test. The average condition of the fish in each enclosure was calculated to avoid pseudoreplication (Hulbert 1984). The mean condition factor of the fish in each enclosure was compared using a $t$-test.

Summer: During June, July, and August we attempted to set up the basic experiment in North, South, Y and Middle Island Ponds. Each time surf-zone fish mortality was usually $100 \%$ following the $24 \mathrm{~h}$ acclimation period (Table 2). It is important to note that this high mortality was observed in multiple ponds and with several fish species each time the experiment was set up. This mortality was unlikely to have been due to transport of the fish; water temperature was kept within 2 to $3^{\circ} \mathrm{C}$ of that in the surf, and dissolved oxygen was kept at saturation levels in the transport containers. In this manner, $M$. martinica could be transported back to the mainland laboratory station with minimal mortality, providing further evidence that handling of the fish was not the primary cause of fish deaths. Instead, the fish deaths were the result of acute physical stresses in the ponds.

Over two $24 \mathrm{~h}$ periods (July 30/31 and August 12/13), we measured dissolved oxygen, temperature, and salinity in the ponds at approximately $4 \mathrm{~h}$ intervals. Salinity and temperature were recorded with a YSI Model 30 SCT meter and dissolved oxygen with a YSI Model 57 D.O. meter. In North, South, and Y Ponds 4 readings were taken at the top, bottom, and middle of the water column in order to account for any stratification (Culberson \& Piedrahita 1996). These measurements suggested extreme fluctuations in both dissolved oxygen and temperature that probably affected the survivorship of the fish species (see 'Results').

To investigate further, we conducted a series of laboratory experiments that assessed species survival under the extreme dissolved oxygen and temperature levels observed in the field. The general design was based on the acute tolerance tests conducted by Dunson et al. (1993). All laboratory tests were conducted at the VCR-LTER in one of four 30 gallon (115.4 l) aquariums. The aquaria were filled with locally collected estuarine water. Five fish species (Membras martinica, the Florida pompano Trachinotus carolinus, the gulf kingfish Menticirrhus littoralis, Fundulus heteroclitus, and Cyprinodon variegatus) were collected from the surf-zone or ponds on Hog Island, and were immediately transported back to the laboratory in aerated containers. The fishes were acclimated to laboratory aquaria for a minimum of $24 \mathrm{~h}$ and fed brine shrimp Artemia sp. to satiation $1 \mathrm{~h}$ before each experiment. At the start of each test, 4 randomly picked specimens of each of the 5 species were placed in a plastic aerated holding tank. Experiments began with the transfer of fishes from the holding tank to the experimental

Table 2. Attempts to introduce the 4 most common surf-zone residents to ponds during the summer of 1998. All fishes were placed in 1 of the field enclosures and then checked on next trip to study site. Survival proportions are averaged across all species. Membras martinica (Mm), Trachinotus carolinus (TC), Menticirrhus littoralis (Ml), Fundulus majalis (Fm)

\begin{tabular}{|c|c|c|c|c|c|c|c|}
\hline \multirow[t]{2}{*}{ Date } & \multirow[t]{2}{*}{ Pond } & \multicolumn{4}{|c|}{ Number introduced } & \multirow{2}{*}{$\begin{array}{c}\text { Total survival } \\
\%\end{array}$} & \multirow{2}{*}{ Days since introduction } \\
\hline & & $M m$ & $T_{C}$ & $M l$ & $F m$ & & \\
\hline Jun 8 & South & 50 & - & - & - & 0 & 3 \\
\hline Jul 1 & North & 50 & - & - & - & 0 & 1 \\
\hline Jul 1 & Middle & 50 & - & - & - & 4 & 2 \\
\hline Jul 1 & $\mathrm{Y}$ & 50 & - & - & - & 4 & 2 \\
\hline Jul 9 & North & 8 & 8 & 8 & - & 0 & 3 \\
\hline Jul 17 & North & 8 & 8 & 8 & 3 & 0 & 1 \\
\hline Jul 17 & South & 8 & 8 & 8 & 0 & 0 & 1 \\
\hline Jul 17 & $\mathrm{Y}$ & 8 & 8 & 8 & 0 & 0 & 1 \\
\hline Jul 24 & $\mathrm{Y}$ & 5 & 6 & 5 & 6 & 0 & 1 \\
\hline Jul 30 & $\mathrm{Y}$ & 5 & 5 & 5 & 5 & 0 & 1 \\
\hline Jul 30 & North & 5 & 5 & 5 & 0 & 0 & 1 \\
\hline Aug 10 & South & 3 & 8 & 4 & 0 & 0 & 1 \\
\hline Aug 10 & North & 4 & 5 & 4 & 0 & 0 & 1 \\
\hline Aug 10 & $\mathrm{Y}$ & 3 & 1 & 11 & 0 & 0 & 1 \\
\hline Aug 12 & South & 5 & 5 & 5 & 1 & 0 & 1 \\
\hline Aug 12 & $\mathrm{Y}$ & 4 & 5 & 14 & 1 & $29^{\mathrm{a}}$ & 1 \\
\hline
\end{tabular}


aquarium. Salinity, temperature, and dissolved oxygen were monitored throughout each test.

Two separate groups of experiments were conducted, one testing fish tolerances to dissolved oxygen extremes and one tolerances to temperature extremes. Dissolved oxygen was adjusted by bubbling nitrogen gas into the aquarium prior to the initiation of the experiment. Acrylic tops covered the tanks to help reduce diffusion of oxygen into the water. Temperature adjustments were made using 3 Penn Plex 15' $200 \mathrm{~W}$ Thermaflow PC Plus heaters. In both sets of experiments, all other physical conditions were kept constant at the standard levels to which the fishes were initially acclimated. The only exception was in the temperature experiments, as the solubility of oxygen decreases with increasing temperature. At higher temperatures, oxygen was kept at saturation levels, concentrations that do not result in short-term fish mortality (Layman unpubl. data). It is possible that fish death was the result of an indirect effect of increased temperature (e.g. increased metabolic demand combined with lower dissolved oxygen levels). However, the purpose of the laboratory experiments was not to pinpoint the exact cause of death, but instead to evaluate relative species mortality under the abiotic conditions observed in the island ponds.

Fish mortality time was recorded at the last observed movement of the opercle (Dunson et al. 1993). For all experiments (4 dissolved oxygen and 2 temperature trials) the time until death for each species was calculated as an average of the individuals from that trial. The dissolved oxygen data were analyzed using an analysis of variance (ANOVA) followed by the Tukey multiple-comparison procedure. Data from the 2 temperature trials did not meet homogeneity of variance assumptions, and were analyzed with a Kruskal-Wallis non-parametric ANOVA.

Fall and winter: The experimental design was modified from the initial spring experiment in order to increase the number of ponds included. A randomized block design (each of the 8 ponds designated in Fig. 1 served as a block) was employed, in which the 3 experimental treatments were established in each pond. The experiment was conducted for $3 \mathrm{wk}$ during the fall of 1998 (October 18 to November 8) and 4 wk in the winter of 1999 (February 15 to March 13). Three sites were excluded from analyses in the fall, and again in the winter, because certain enclosures were overturned by the wind or the enclosure mesh damaged by blue crabs Callinectes sapidus, either of which allowed the experimental fishes to escape. Proportional survival data were arcsine-transformed as described above, and then analyzed by 2-way ANOVA with pond serving as a blocking variable. The mean condition of fishes within each enclosure was calculated and values com- pared with the same ANOVA design. When significant p-values were found using ANOVA, the Tukey posthoc test was used to make pairwise comparisons among treatments. All statistical analyses were conducted with SigmaStat Statistical Software (1997). The design of the seasonal experiments is summarized in Fig. 2.

Due to logistical difficulties, the experiments were set up slightly differently in each season (e.g. the time over which each experiment was conducted). However, the intention was not to make comparisons among all seasons, but instead to focus on the differences between the summer and non-summer months. Because of the unavoidable differences in experimental design in the non-summer months, no comparisons were made among fall, winter, and spring data.

\section{RESULTS}

\section{Spring}

In Treatment 1, Membras martinica survival averaged $92 \%$ (Fig. 3), significantly higher than the $42 \%$ observed in Treatment 3 ( $t$-test, $\mathrm{df}=4, t=4.6, \mathrm{p}=0.01$ ). Likewise, the mean condition of $M$. martinica in Treatment 1 was significantly higher than in Treatment 3 ( $t$-test, $\mathrm{df}=4, t=2.9, \mathrm{p}=0.04)$. The relatively high survival (compared to summer survival times) suggests that physical conditions in the ponds, although potentially providing a long-term chronic stress on the fishes, did not preclude their prolonged survival over the 5 wk study period. In Treatment 3, survival and condition of the surf-zone fishes were significantly reduced. None of the Fundulus heteroclitus died during the spring experiment.

\section{Summer}

We attempted to set up the same experiment in 4 ponds throughout the summer using the most common shallow surf-zone fish species, but mortality was almost always $100 \%$ after $24 \mathrm{~h}$ (Table 2). Only minutes after their introduction into the ponds, the behavior of the fishes was noticeably affected. Some surf-zone fishes died during the afternoon hours when temperatures reached a maximum, but most died soon after sunset as dissolved oxygen decreased significantly; in most cases, all surf fishes were dead by the following morning. One exception to this pattern was on August 12 in Y Pond when some surf-zone fishes were able to survive for $24 \mathrm{~h}$. This increased survival coincided with an over-wash event that served to temporarily ameliorate the physical conditions in the pond. Even so, all 

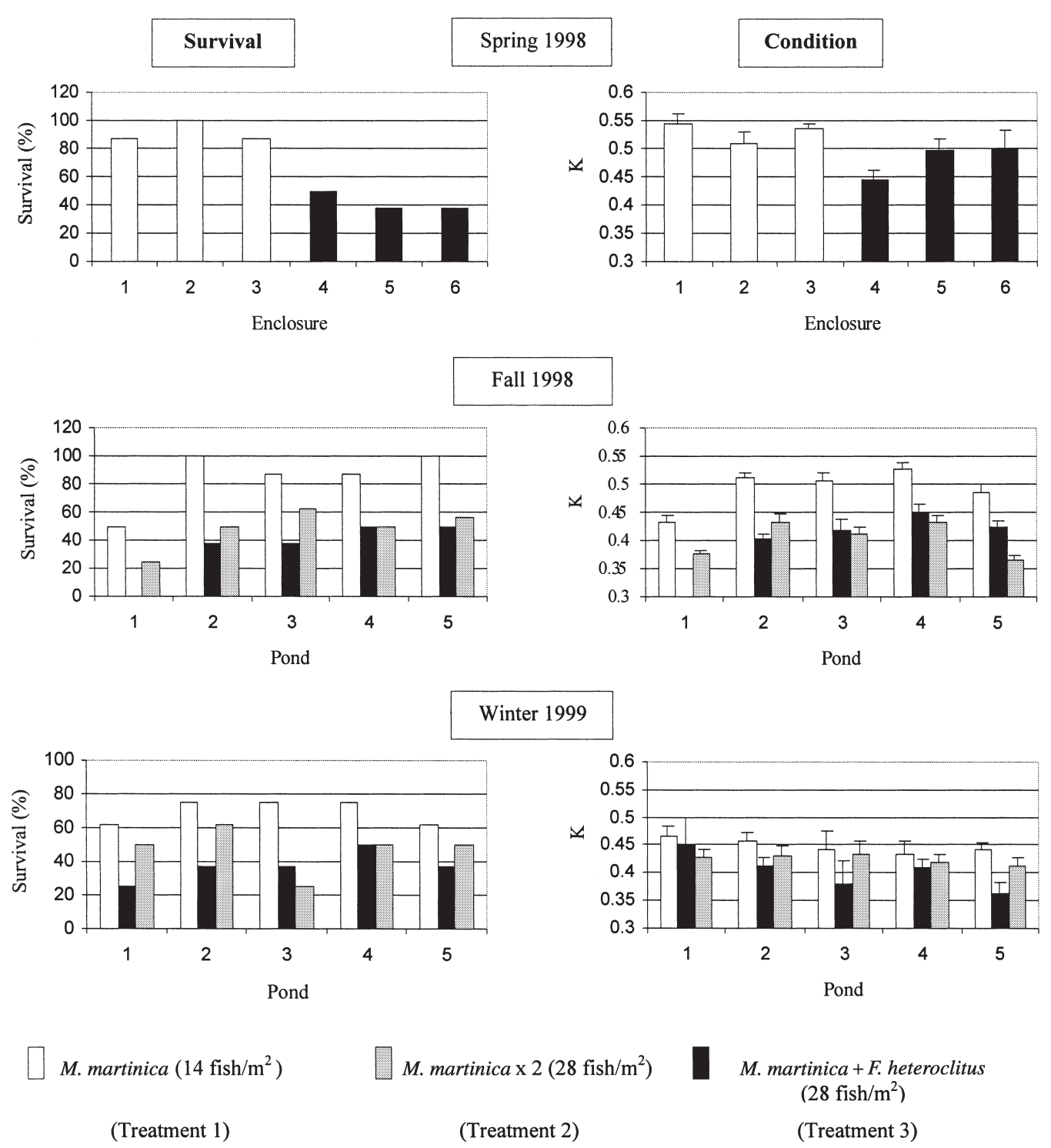

Fig. 3. Membras martinica. Percentage surviving during each seasonal experiment and average condition $(K)$ of fish that survived. In right-hand panels, error bars represent $\pm 1 \mathrm{SE}_{\text {; }}$ these errors are calculated with $\mathrm{n}$ as number of surviving fish in that pond or enclosure

the surf-zone fishes were dead within $4 \mathrm{~d}$ as physical conditions again deteriorated. In contrast, resident marsh species, Fundulus heteroclitus and Cyprinodon variegatus survived the entire summer in the enclosures.

The $24 \mathrm{~h}$ profiles of dissolved oxygen and temperature during the summer suggest extremely stressful physical conditions (Fig. 4). Dissolved oxygen levels were not limiting during the daylight hours, reaching levels as high as $20 \mathrm{mg} \mathrm{l}^{-1}$ in one of the ponds. Immediately following sunset, however, the dissolved oxygen levels fell dramatically. In all 3 ponds on July 30, and 2 of the 3 ponds on August 12, the dissolved oxy- gen level was $0.1 \mathrm{mg} \mathrm{l}^{-1}$ before midnight. Dissolved oxygen levels remained extremely low until sunrise when photosynthesis began to re-oxygenate the water. Temperature readings during the afternoon reached $38^{\circ} \mathrm{C}$ on July 30 , but readings as high as $41^{\circ} \mathrm{C}$ have been observed in shallow ponds on Hog Island (Layman pers. obs.). Fig. 4 depicts mid-water measurements, but the trends and extremes of dissolved oxygen and temperature were similar throughout the water column. Salinities varied less than $1.0 \mathrm{ppt}$ during the $24 \mathrm{~h}$ measurement periods, and remained at levels that were not likely to cause short-term surf fish mortality (20 to $35 \mathrm{ppt}$ ). 


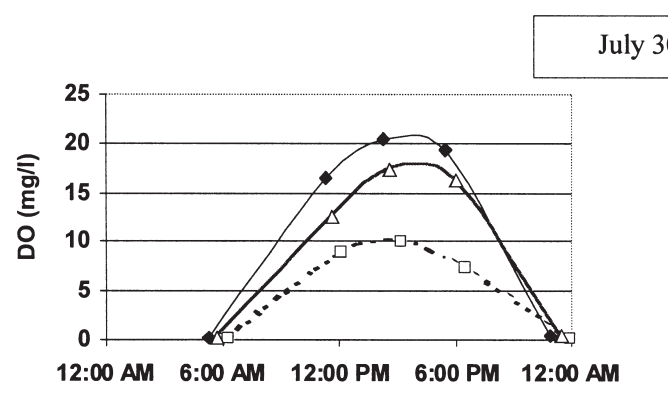

July $30 / 31$

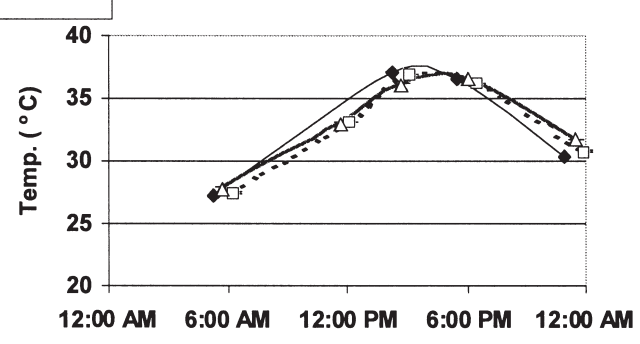

August $12 / 13$
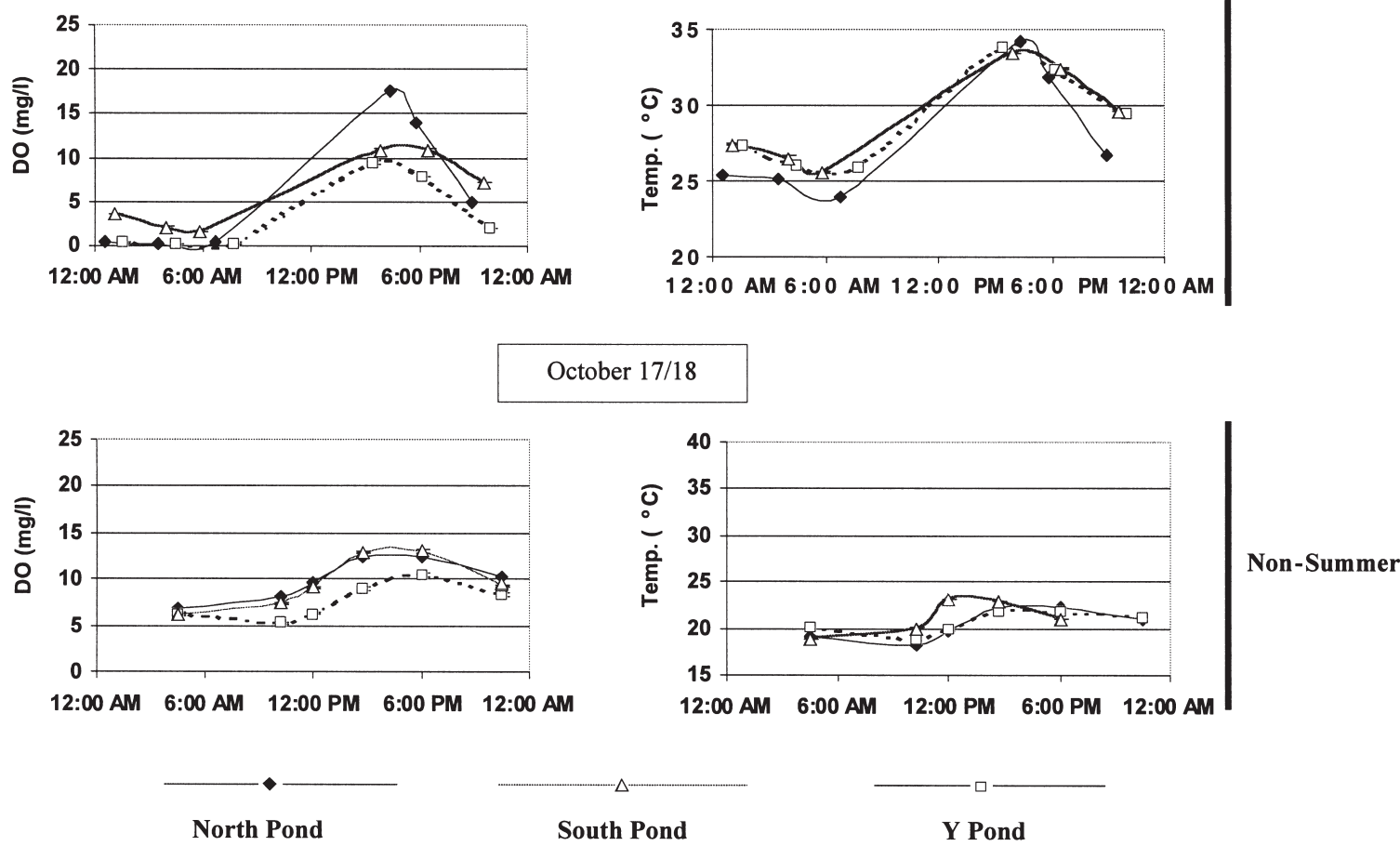

Fig. 4. Dissolved oxygen (DO) and temperature profiles over 24 h periods on July 30/31, August 12/13, and October 17/18, 1997, in North, South and Y Ponds. July and August cycles are representative of the summer (dry) season and October profiles of corresponding cycles in a non-summer (wet) season. Readings in these panels are based on average value of measurements taken at random locations in each pond

Laboratory experiments supported the above findings (Fig. 5). At each oxygen level (all of which were less severe than those commonly observed in the ponds) the surf-zone fishes were able to survive for only a matter of minutes. In sharp contrast, only 1 marsh fish died during all the laboratory experiments. There were clear differences in the mean time of survival (ANOVA, $F_{4,15}=21.4$, $\mathrm{p}<0.001$ ). The pairwise comparisons (Table 3 ) revealed 2 distinct statistical groups of fishes corresponding to their primary habitat. It was not possible statistically to distinguish among mean survival time within the surfzone or marsh-fish groupings. The same pattern was apparent in the temperature experiments; all the resident marsh fishes survived until the end of the experiment, but the surf-zone fishes died after only minutes. The difference in survival time was not significant (KruskalWallis, $\mathrm{df}=4, H=8.4, \mathrm{p}=0.08$ ), but this may be due to the low number of replicates which limited the power of the test. Additional trials would probably result in a statistically significant result.

Fall

Average survival of Membras martinica in the 3 treatments was found to be significantly different 

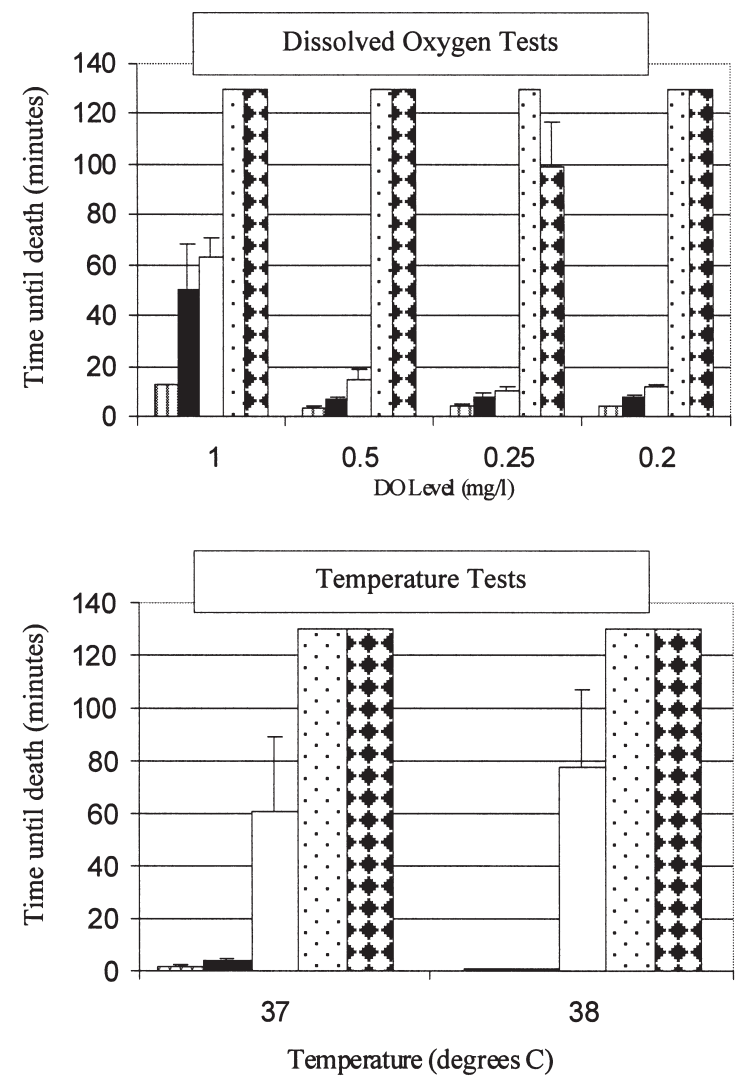

Surf-zone species

Resident marsh species

IIII Menticirrhus littoralis

Membras martinica

$\because \therefore$ Fundulus heteroclitus
8 Cyprinodon variegatus

\section{Trachinotus carolinus}

Fig. 5. Results of the 2 sets of laboratory tests examining the acute tolerances of fishes to extreme dissolved oxygen (DO) and temperature levels. All other physio-chemical variables were held at non-stressful levels during the tests. Each bar represents the mean $( \pm 1 \mathrm{SE})$ of 4 individuals of each species. Each experiment was terminated after $130 \mathrm{~min}$

(ANOVA, $F_{2,12}=10.3, \mathrm{p}=0.002$ ): $85 \%$ for Treatment 1 , $49 \%$ for Treatment 2 , and $35 \%$ for Treatment $3 . M$. martinica were able to survive for the entire $3 \mathrm{wk}$ study period, but survival was significantly reduced at increased fish densities. Likewise, the condition of fish differed significantly among all treatments (ANOVA, $F_{2,11}=10.7, \mathrm{p}=0.003$ ) because of the lower values found in the higher density treatments. These results suggest that biological factors are playing a role in the reduced ability of the surf-zone fishes to persist. There was no obvious trend between the survival or condition of the fishes in the 2 higher density treatments. Fundulus heteroclitus survival was $100 \%$ in each of the enclosures. The fall profiles of dissolved oxygen and temperature differed substantially from those observed in the summer (Fig. 4). Afternoon water temperatures reached only $24^{\circ} \mathrm{C}$ and the dissolved oxygen profile was less extreme, reaching $13 \mathrm{mg} \mathrm{l}^{-1}$ during the day and only falling to about $5 \mathrm{mg} \mathrm{l}^{-1}$ at night.

\section{Winter}

Average Membras martinica survival in Treatment 1 was $70 \%$, but was reduced to $48 \%$ in Treatment 2 and $38 \%$ in Treatment 3 . Survival was significantly different among all treatments (ANOVA, $F_{2,12}=5.5, \mathrm{p}=$ 0.02). There was no consistent difference in survival between Treatments 2 and 3. The mean condition of fishes also was significantly different (ANOVA, $F_{2,12}=$ $5.8, \mathrm{p}=0.001)$. The condition of fishes in the low-density enclosures was higher than that in the other 2 treatments in each of the 5 ponds. Only a single Fundulus heteroclitus died in all 5 ponds during the course of the winter experiments.

\section{DISCUSSION}

This study demonstrates that local mortality of surfzone fishes in marsh ponds is likely caused both by susceptibility to abiotic factor extremes (i.e. dissolved oxygen and temperature) and biotic factors. Previous models (i.e. Menge \& Sutherland 1987) concerning the importance of abiotic and biotic structuring mechanisms are based on a spatial gradient of environmental stress. Here, we identify a temporal environmental stress gradient. During summer, dissolved oxygen and temperature reach extreme levels, resulting in surf-zone fish mortality. During non-summer months, dissolved oxygen and temperature levels are moderated, allowing biological interactions to become relatively more important. The structuring mechanisms in summer and non-summer periods are considered separately below.

Table 3. Menticirrhus littoralis (Ml), Membras martinica (Mm), Trachinotus carolinus ( $T C)$, Fundulus heteroclitus (Fh), Cyprinodon variegatus $(\mathrm{CV})$. p-values generated from Tukey pairwise comparisons following significant 1-way ANOVA on mean time until death of fishes. ${ }^{*}$ Significant $\mathrm{p}$-value, a,b: statistical groupings based on pairwise comparisons

\begin{tabular}{|lccccc|}
\hline & $M l_{\mathrm{a}}$ & $M m_{\mathrm{a}}$ & $T C_{\mathrm{a}}$ & $F h_{\mathrm{b}}$ & $C V_{\mathrm{b}}$ \\
\hline$M l_{\mathrm{a}}$ & - & - & - & - & - \\
$M m_{\mathrm{a}}$ & 0.83 & - & - & - & - \\
$T C_{\mathrm{a}}$ & 0.51 & 0.98 & - & - & - \\
$F h_{\mathrm{b}}$ & $<0.001^{*}$ & $<0.001^{*}$ & $<0.001^{*}$ & - & - \\
$C V_{\mathrm{b}}$ & $<0.001^{*}$ & $<0.001^{*}$ & $<0.001^{*}$ & 0.96 & - \\
\hline
\end{tabular}




\section{Summer structuring mechanisms}

During summer months, pond temperatures exceeded $41^{\circ} \mathrm{C}$, well above the short-term tolerance limits of the surf-zone fishes. The combination of warm water temperatures and benthic decomposition, as well as respiration by fishes, invertebrates, and algae in the ponds, resulted in near anoxic conditions at night. A pattern of high afternoon temperatures and low night-time dissolved oxygen levels has been reported in similar pond habitats (Kushlan 1979, Krom et al. 1985a,b, Whoriskey \& Fitzgerald 1987, Culberson $\&$ Piedrahita 1996). Other physio-chemical variables, including low pH (Haines 1981, Horne \& Dunson 1995), high ammonia levels (Krom et al. 1985b), and extreme salinities may have also contributed to the death of the surf-zone fishes; however, either the observed dissolved oxygen or temperature extremes alone can account for the rapid surf-zone fish mortality during summer.

The most abundant fishes in the Virginia island marsh ponds, Fundulus heteroclitus and Cyprinodon variegatus, are extremely tolerant of such harsh conditions. F. heteroclitus has been shown to survive for extended periods in temperatures ranging from $-1.5^{\circ} \mathrm{C}$ (Umminger 1972) to $36^{\circ} \mathrm{C}$ (Garside \& Chin-Yuen-Kee 1972). C. variegatus has been found in waters with salinities ranging from 0 to $142 \mathrm{ppt}$ (Simpson \& Gunter 1956, Nordlie 1985, Dunson et al. 1998) and F. heteroclitus from 0 to $120 \mathrm{ppt}$ (Griffith 1974). C. variegatus is considered the most eurythermic of all fishes, with critical thermal minima and maxima ranging from 0.6 to $45.1^{\circ} \mathrm{C}$ (Bennet \& Beitinger 1996). Both these species are also extremely well-adapted to low dissolved oxygen conditions through morphological (Lewis 1970) and behavioral adaptations (Kramer 1987). For example, F. heteroclitus increases aquatic surface respiration in low dissolved oxygen conditions, as has been documented for other fishes (Lewis 1970, Gee et al. 1978, Congleton 1980, Kramer \& Mehegan 1981, Kramer \& McClure 1982).

In addition to causing surf-zone fish mortality, the extreme environmental stress of the ponds probably affects the relative abundance of resident marsh fishes. For example, large Fundulus heteroclitus were more likely to perish under hypoxic conditions than were juvenile conspecifics or the smaller Cyprinodon variegatus (Layman per. obs.). Kushlan (1974) similarly found that large fishes were more susceptible to stresses during dry periods in the Everglades, perhaps because larger fishes have a higher oxygen demand (Jobling 1994, Moyle \& Cech 1996). Dunson et al. (1993) described the tolerances exhibited by marsh fishes to physio-chemical extremes and suggested that these may have important implications for community structure. Dunson \& Travis (1994) discuss the importance of abiotic variables on estuarine communities. The present study further emphasizes the role that physical conditions have on marsh-pond fish-community structure, especially during environmentally stressful time periods.

Biotic interactions also may play a role in determining the relative abundance of species in the summer. In fact, as ponds shrink during drier months, fishes are forced into smaller areas, perhaps increasing competition for limiting resources (Zaret \& Rand 1971, LoweMcConnell 1987, Winemiller 1989). Shrinking ponds are excellent feeding areas for various species of wading and shore birds (Kushlan 1976b, 1986, Kneib 1982, Master 1992), and blue crabs (Kneib 1982). Therefore, dominant abiotic structuring parameters do not eliminate intense biological interactions that may occur among species that can tolerate the environmental stress of the ponds. As Matthews (1998) suggests, physical harshness may provide a filter that precludes existence of some species (see Smith \& Powell 1971), but this does not necessarily reduce the importance of biotic interactions on the individuals that are able to persist. However, this study suggests that abiotic factors are the overwhelmingly dominant communitystructuring mechanisms during the summer.

\section{Non-summer structuring mechanisms}

Membras martinica exhibited high survival in 'control' cages during non-summer months, but survival and condition of survivors were significantly reduced with higher fish densities. These experiments, using an in situ approach which had not previously been attempted in such a system, provide evidence that biotic interactions may affect the relative abundance of fishes in marsh ponds. In the high-density $M$. martinica treatment, competition for food was likely to have affected the survival and/or growth of M. martinica. Competition has been found to be an important structuring mechanism for fish assemblages in rocky intertidal habitats (Grossman 1982) and in freshwater streams (Ross et al. 1985, Matthews 1998). Other studies suggest that intra-specific competition (Rubenstein 1981, Persson 1983, Wooton 1985) can have detrimental effects on the growth, reproductive success, or resource utilization of fishes. We conclude that it is not yet clear to what extent competition contributes to patterns in marsh-pond fish-community structure, but our results suggest that during periods of reduced environmental stress, competition may indeed be a key community-structuring element.

Fundulus heteroclitus can consume a wide range of food items (Fritz 1974, Baker-Dittus 1978, Kneib \& 
Stiven 1978, Kneib et al. 1980, Kneib 1986), whereas Membras martinica are primarily zooplanktivorous (Bengston 1984, Morgan 1990, Allen et al. 1995). Thus, direct food competition between these 2 species would not be expected. Whatever the nature of the effect, the significantly reduced survival and condition of M. martinica indicates that there was some biological interaction between the species, be it direct or indirect. This suggests that a biotic factor is affecting fish survival during seasons characterized by reduced environmental stress.

The Menge \& Sutherland (1987) model predicts that the impact of predation on community structure will increase as physical harshness decreases. It was beyond the scope of this study to evaluate this model prediction, but field observations support the hypothesis that predation may also contribute to the patterns in species abundance. At dissolved oxygen levels of 2 to $4 \mathrm{mg} \mathrm{l}^{-1}$, surf-zone fishes are able to survive for extended time periods in the ponds, but their behavior is noticeably affected. These fishes frequent the top of the water column, becoming easily detectable to avian predators. On numerous occasions surf-zone and resident marsh fishes were placed in one of the experimental enclosures without the protective screen. Birds, including Ardea herodias (great blue herons), Casmerodius albus (great white egrets), and Egretta thula (snowy egrets), could easily feed on the surf fishes, but few of the marsh fish species were captured. Marsh fishes are able to more effectively utilize benthic refugia, even under relatively low dissolved oxygen conditions. Abiotic conditions in the ponds may be influencing the behavior of the fishes, indirectly mediating a biological interaction (predation), and subsequently influencing fish-community structure. For example, Kramer et al. (1983) demonstrated that oxygen levels can affect the rate of predation by herons on fishes and Frederick \& Loftus (1993) suggested that temperature may affect the interaction of wading-bird predators and marsh fish resident prey. Experimental manipulations designed to demonstrate predation effects were not included in the present study; instead, a general seasonal shift in the importance of community-structuring mechanisms was described. This may serve as a framework for future efforts that more thoroughly describe the numerous important biotic structuring mechanisms.

Physical factors may also play other prominent roles in structuring of fish communities during non-summer months. For example, cold winter temperatures are more likely to be detrimental to the surf-zone fishes (Snelson \& Bradley 1978, Hall et al. 1982) than to the tolerant resident marsh fishes. Additionally, the harshness of the environment may lower the threshold at which competition becomes detrimental to a particular species, making competitive exclusion more likely (Holt 1985, Chesson \& Huntly 1997). To illustrate, Membras martinica kept under conditions of low dissolved oxygen in laboratory aquaria became sluggish and were slower to feed. When M. martinica were held in the same tank as Fundulus heteroclitus, the F. heteroclitus (seemingly unaffected by the chronically low dissolved oxygen conditions) would quickly consume food before $M$. martinica would even begin to feed (Layman pers. obs.). Such a reduced inclination to feed in low oxygen conditions has been observed for a variety of fish species (Petit 1973, Carlson et al. 1980, Weber \& Kramer 1983, Whoriskey et al. 1985).

\section{Study limitations}

Our study has 2 major limitations: (1) the inherent difficulties of demonstrating competition or other biotic effects using enclosure experiments, and (2) a relatively short experimental study period.

First, confining mobile organisms may alter behavior and make it problematic to deduce natural community properties (Connell 1983). Additionally, indirect interactions, such as food availability, may confuse the mechanisms behind observed responses (Connell 1983, Bender et al. 1984, Tilman 1987). Finally, the structure of the enclosures themselves may alter physical conditions and disrupt the natural relationship between organisms (Rothschild \& Osborn 1988, MacKenzie \& Leggett 1991). In spite of these limitations, other fish assemblage studies have utilized enclosures (Rubenstein 1981, Bergman 1990, Persson \& Greenberg 1990, Dieter et al. 1991, Abrahams 1996, Duffy et al. 1996), largely because this approach provides the best possible representation of the natural physical and chemical environment. We minimized experimental artifacts by using permeable enclosures, replicating the experiment in several ponds, and by setting our experimental densities at naturally occurring levels. These considerations make 'scaling-up' from the experiments to entire pond fish communities seem reasonable.

Second, our experiments were conducted over the course of a single year. Despite this drawback, we have studied ponds on the Virginia barrier islands since 1995, and the same water-level pattern and associated pond dynamics have been observed each year. Longterm water-level data for Hog Island supports this observation (see database of VCR-LTER: http://atlantic. evsc.virginia.edu/data.html\#physical). This pattern is similar to that thoroughly described for the Florida Everglades (Kushlan 1976a,b, 1980, 1986). Thus, the results presented here may provide a basis for future studies in similar systems. Such studies might consider how spatial variability (i.e. food availability, depth, or 
substrate of ponds), the inclusion of different fish species, or differing regional study sites might affect community-structuring mechanisms.

\section{Conclusion}

Previous studies that have assessed the importance of community-structuring mechanisms have typically taken a spatially oriented approach. This study demonstrates that community-structuring mechanisms may vary seasonally due to fluctuating environmental stress. Our data suggest that abiotic parameters determine community structure during harsh summer periods which are characterized by low dissolved oxygen and high temperature. Biotic interactions may become more important in shaping communities as environmental stress moderates in non-summer months. Since the water level of ponds on the islands follows a reasonably predictable seasonal pattern, the relative importance of the structuring mechanisms may be predicted using a seasonal gradient of environmental stress. This temporally oriented framework could be used as a working hypothesis in future studies that seek to assess the importance of community-structuring mechanisms.

Acknowledgements. Special thanks to G. Carleton Ray, Micheal Erwin, Brian R. Silliman, and 3 anonymous reviewers, who provided excellent comments that greatly improved this manuscript. Others, too numerous to name here, provided valuable assistance with fieldwork. This work was supported by the VCR-LTER Project and the Fred Holmesly Moore Research Grant through the University of Virginia Department of Environmental Sciences.

\section{LITERATURE CITED}

Abrahams MV (1996) Interaction between young-of-the-year fathead minnows and brook sticklebacks: effects on growth and diet selection. Trans Am Fish Soc 125:480-485

Allen DM, Johnson WS, Ogburn-Matthews V (1995) Trophic relationships and seasonal utilization of salt-marsh creeks by zooplanktivorous fishes. Environ Biol Fish 42:37-50

Baker-Dittus AM (1978) Foraging patterns of three sympatric killifish. Copeia 1978:383-389

Bender EA, Case TJ, Gilpin ME (1984) Perturbation experiments in community ecology: theory and practice. Ecology 65:1-13

Bengston DA (1984) Resource partitioning by Menidia menidia and Menidia beryllina (Osteichthyes: Atherinidae). Mar Ecol Prog Ser 18:21-30

Bennet WA, Beitinger TL (1996) Extreme thermal tolerance of the sheepshead minnow, Cyprinodon variegatus. Annual Meeting. American Society of Ichthyologists and Herpetologists, 1996, p 1 (Abstract)

Bergman E (1990) Effects of roach Rutilus rutilus on two per- cids, Perca flaviatilis and Gymnocephalus cernua: importance of species interactions for diet shifts. Oikos 57: 241-249

Carlson AR, Blocher J, Herman LJ (1980) Growth and survival of channel catfish (Ictalurus punctatus) embryos and larvae. Trans Am Fish Soc 103:623-626

Chesson P, Huntly N (1997) The roles of harsh and fluctuating conditions in the dynamics of ecological communities. Am Nat 150(5):519-553

Congleton JL (1980) Observations on the responses of some Southern California tidepool fishes to nocturnal hypoxic stress. Comp Biochem Physiol 66a:719-722

Connell JH (1975) Some mechanisms producing structure in natural communities: a model and evidence from experiments. In: Cody ML, Diamond JM (eds) Ecology and evolution of communities. Belknap Press, Cambridge, MA, p 460-490

Connell JH (1983) On the prevalence and relative importance of interspecific competition: evidence from field experiments. Am Nat 122(5):661-696

Connell JH (1985) The consequences of variation in initial settlement vs. post settlement mortality in rocky high intertidal communities. J Exp Mar Biol Ecol 93:11-45

Culberson SD, Piedrahita RH (1996) Aquaculture pond ecosystem model: temperature and dissolved oxygen prediction-mechanism and application. Ecol Model 89: 231-258

Dayton PK (1971) Competition, disturbance and community organization: the provision and subsequent utilization of space in a rocky intertidal community. Ecol Monogr 41:351-389

Dieter CD, Berry CR Jr, Kolterman B (1991) Fish enclosures for research in marshes. Wetlands 11(1):173-177

Duffy JT, Epifanio CE, Cope JS (1996) Effects of prey density on the growth and mortality of weakfish Cynoscion regalis larvae: experiments in field enclosures. J Exp Mar Biol Ecol 202:191-203

Dunson WA, Rowe CL (1996) The effect of species manipulation on growth and survival of an assemblage of juvenile estuarine fish. J Fish Biol 48:120-130

Dunson WA, Travis J (1994) Patterns in the evolution of physiological specialization in salt-marsh animals. Estuaries 17:102-110

Dunson WA, Friacano P, Sadinski WJ (1993) Variation in tolerance to abiotic stresses among sympatric salt marsh fish. Wetlands 13:16-24

Dunson WA, Paradise CJ, Dunson DB (1998) Inhibitory effect of low salinity on growth and reproduction of the estuarine sheepshead minnow, Cyprinodon variegatus. Copeia 1998: 235-239

Everhart WH, Youngs WD (1981) Principles of fishery science. Cornell University Press, Ithaca, NY

Franks JS (1970) An investigation of the fish population within the headland waters of Horn Island, Mississippi, a barrier island in the northern Gulf of Mexico. Gulf Res Rep 3:3-104

Frederick PC, Loftus WF (1993) Responses of marsh fishes and breeding wading birds to low temperatures: a possible behavioral link between predator and prey. Estuaries 16:216-222

Fritz ES (1974) Total diet comparison in fishes by Spearman rank correlation coefficients. Copeia 1974:210-214

Garside ET, Chin-Yuen-Kee ZK (1972) Influence of osmotic stress on upper lethal temperatures in the cyprinodontid fish Fundulus heteroclitus. Can J Zool 50:787-791

Gee JH, Tallman RF, Smart HJ (1978) Reactions of some Great Plains fishes to progressive hypoxia. Can J Zool 56: 1962-1966 
Griffith RW (1974) Environmental and salinity tolerance in the genus Fundulus. Copeia 1974:319-331

Grossman GD (1982) Dynamics and organization of a rocky intertidal fish assemblage: the persistence and resilience of taxocene structure. Am Nat 119:611-637

Haines TA (1981) Acidic precipitation and its consequences for aquatic systems: a review. Trans Am Fish Soc 110(6): 669-707

Hall LW, Burton DT, Abell BR (1982) Thermal responses of Atlantic silversides (Menidia menidia) acclimated to constant and asymmetric flutuating temperatures. Arch Hydrobiol 94(3):318-325

Hansen RA, Hart DD, Merz RA (1991) Flow mediates predator-prey interactions between triclad flatworms and larval blackflies. Oikos 60:187-196

Holt RD (1985) Density-independent mortality, non-linear competitive interactions, and species co-existence. J Theor Biol 116:479-493

Horne MT, Dunson WA (1995) The interactive effects of low $\mathrm{pH}$, toxic metals, and DOC on a simulated temporary pond community. Environ Pollut 89:155-161

Hurlbert SH (1984) Pseudoreplication and the design of ecological field experiments. Ecol Monogr 54(2):187-211

Huston MA (1994) Biological diversity: the coexistence of species on changing landscapes. Cambridge University Press, Cambridge

Jobling M (1994) Fish bioenergetics. Chapman \& Hall, New York

Kneib RT (1982) The effects of predation by wading birds (Ardeidae) and blue crabs (Callinectes sapidus) on the population size structure of the common mummichog, Fundulus heteroclitus. Estuar Coast Shelf Sci 14(2):159-165

Kneib RT (1986) The role of Fundulus heteroclitus in salt marsh trophic dynamics. Am Zool 26:259-269

Kneib RT, Stiven AE (1978) Growth, reproduction, and feeding of Fundulus heteroclitus on a North Carolina salt marsh. J Exp Mar Biol Ecol 31:121-140

Kneib RT, Stiven AE, Haines EB (1980) Stable carbon isotope ratios in Fundulus heteroclitus muscle tissue and gut contents from a North Carolina Spartina marsh. J Exp Mar Biol Ecol 46:89-98

Kramer DL (1987) Dissolved oxygen and fish behavior. Environ Biol Fish 18(2):81-92

Kramer DL, McClure M (1982) Aquatic surface respiration, a widespread adaptation to hypoxia in tropical freshwater fishes. Environ Biol Fish 7:47-55

Kramer DL, Mehegan JP (1981) Aquatic surface respiration, an adaptive response to hypoxia in the guppy, Poecilia reticulata (Pisces, Poeciliidae). Environ Biol Fish 6:299-313

Kramer DL, Manley D, Bourgeois R (1983) The effect of respiratory mode and oxygen concentration on the risk of aerial predation in fishes. Can J Zool 61:653-665

Krom MD, Porter C, Gordin H (1985a) Description of water quality conditions in a semi-intensively cultured marine fish pond in Eilat, Israel. Aquaculture 49:141-157

Krom MD, Porter C, Gordin H (1985b) Causes of fish mortality in semi-intensively operated seawater ponds in Eilat, Israel. Aquaculture 49:159-177

Kushlan JA (1974) Effects of a natural fish kill on the water quality, plankton, and fish population of a pond in the Big Cypress Swamp, Florida. Trans Am Fish Soc 103:235-243

Kushlan JA (1976a) Environmental stability and fish community diversity. Ecology 57:821-825

Kushlan JA (1976b) Wading bird predation in a seasonally fluctuating pond. Auk 93:464-476

Kushlan JA (1979) Temperature and oxygen in an Everglades alligator pond. Hydrobiologia 67(3):267-271
Kushlan JA (1980) Population fluctuations of Everglades fishes. Copeia 1980:870-874

Kushlan JA (1986) Responses of wading birds to seasonally fluctuating water levels: strategies and their limits. Colon Waterbirds 9(2):155-162

Lancaster J (1990) Predation and drift of lotic macroinvertebrates during colonization. Oecologia 85:48-56

Lancaster J (1996) Scaling the effects of predation and disturbance in a patchy environment. Oecologia 107:321-331

Layman CA (1999) Fish assemblage structure in shallow water habitats on Eastern Shore of Virginia barrier islands. Master's thesis, University of Virginia, Charlottesville

Layman CA (2000) Fish assemblage structure of the shallow ocean surf-zone on the eastern shore of Virginia barrier islands. Estuar Coast Shelf Sci 51:201-213

Leonard GH, Levine JM, Schmidt PR, Bertness MD (1998) Flow-driven variation in intertidal community structure in a Maine estuary. Ecology 79:1395-1411

Lewis WM Jr (1970) Morphological adaptations of cyprinodontids for inhabiting oxygen deficient waters. Copeia 1970:319-326

Loftus WF, Eklund A (1994) Long-term dynamics of an Everglades small-fish assemblage. In: Davis SM, Ogden JC (eds) Everglades: the ecosystem and its restoration. St. Lucie Press, Boca Raton, FL, p 461-483

Lowell-McConnel RH (1987) Ecological studies in tropical fish communities. Cambridge University Press, Cambridge

MacKenzie BR, Leggett WC (1991) Quantifying the contribution of small-scale turbulence to the encounter rates between larval fish and their zooplankton prey: effects of wind and tide. Mar Ecol Prog Ser 73:149-160

Master TL (1992) Composition, structure, and dynamics of mixed-species foraging aggregations in a southern New Jersey salt marsh. Colon Waterbirds 15(1):66-74

Matthews WJ (1998) Patterns in freshwater fish ecology. Chapman \& Hall, New York

Menge BA (1976) Organization of the New England rocky intertidal community: role of predation, competition and environmental heterogeneity. Ecol Monogr 46:355-393

Menge BA (1978a) Predation intensity in a rocky intertidal community: relation between foraging activity and environmental harshness. Oecologia 34:1-16

Menge BA (1978b) Predation intensity in a rocky intertidal community: effect of algal canopy, wave action and desiccation on predator feeding rates. Oecologia 34:17-35

Menge BA (1983) Components of predation intensity in the low zone of the New England rocky intertidal community. Oecologia 58:141-155

Menge BA, Farrell TM (1989) Community structure and interaction webs in shallow marine hard bottom communities: tests of an environmental stress model. Adv Ecol Res 19: 189-262

Menge BA, Sutherland JP (1987) Community regulation: variation in disturbance, competition and predation in relation to environmental stress and recruitment. Am Nat 130:730-757

Menge BA, Farrell TM, Olson AM, van Tamelen P, Turner T (1993) Algal recruitment and the maintenance of a plant mosaic in the low intertidal region of the Oregon coast. J Exp Mar Biol Ecol 170:91-116

Morgan SG (1990) Impact of planktivorous fishes on dispersal, hatching, and morphology of estuarine crab larvae. Ecology 71:1639-1652

Moyle PB, Cech JJ Jr (1996) Fishes. An introduction to ichthyology. Prentice Hall, Englewood Cliffs, NJ

Nordlie FG (1985) Osmotic regulation in the sheepshead minnnow Cyprinodon variegatus. J Fish Biol 26:161-170 
Peckarsky BL (1983) Biotic interactions or abiotic limitations? A model of lotic community structure. In: Fontaine TD III, Bartell SM (eds) Dynamics of lotic ecosystems. Ann Arbor Science, Ann Arbor, MI

Peckarsky BL, Horn SC, Statzner B (1990) Stonefly predation along a hydraulic gradient: a test of the harsh benign hypothesis. Freshw Biol 24:181-191

Persson L (1983) Food consumption and competition between age classes in a perch Perca fluviatilis population in a shallow eutrophic lake. Oikos 40:197-202

Persson L, Greenberg L (1990) Juvenile competitive bottlenecks: the perch (Perca fluviatilis)-roach (Rutilus rutilius) interaction. Ecology 71(1):44-56

Petit GD (1973) Effects of dissolved oxygen on survival and behavior of selected fishes of western Lake Erie. Bull Ohio Biol Surv 4:1-76

Poulin R, Fitzgerald GJ (1989) Early life histories of three sympatric sticklebacks in a salt marsh. J Fish Biol 34:207-221

Ross ST, Doherty TA (1994) Short-term persistence and stability of barrier island fish assemblages. Estuar Coast Shelf Sci 38:49-67

Ross ST, Matthews WJ, Echelle AA (1985) Persistence of stream fish assemblages: effects of environmental change. Am Nat 126:24-40

Rothschild BJ, Osborn TR (1988) Small-scale turbulence and plankton contact rates. J Plankton Res 10:455-464

Rowe CL, Dunson WA (1995) Individual and interactive effects of salinity and initial fish density on a salt marsh assemblage. Mar Ecol Prog Ser 128:271-278

Rubenstein DI (1981) Individual variation and competition in the Everglades pygmy sunfish. J Anim Ecol 50(2):337-350

Schwartz FJ (1988) Pre- and post-drought fish surveys of selected freshwater ponds located in Nags Head Woods, Nags Head, North Carolina. Bull Assoc SEast Biologists 35:189-198

Schwartz FJ, Safrit G, Jensen C, Purifoy J (1990a) Long-term ecological stability of fish faunas in natural and man-made coastal ponds subjected to shifting marine and freshwater conditions. J Aquat Org 3:1-6

Schwartz FJ, Safrit G, Jensen C, Purifoy J (1990b) Stability and persistence of the fishes inhabiting Mullet Pond, Shackleford Banks, North Carolina 1903-1989. J Elisha Mitchell Sci Soc 106:38-50

Editorial responsibility: Otto Kinne (Editor), Oldendorf/Luhe, Germany
SigmaStat Statistical Software ${ }^{\circledR}$ (1997) Version 2.0. SPSS, Inc, p 395

Simpson DG, Gunter G (1956) Notes on habitats, systematic characteristics and life histories of Texas salt-water cyprinodontes. Tulane Stud Zool 4:115-134

Smith CL, Powell CR (1971) The summer fish communities of Brier Creek, Marshall County, Oklahoma. Am Mus Novit 2458:1-30

Snelson FF Jr, Bradley WK Jr (1978) Mortality of fishes due to cold on the east coast of Florida, January, 1977. Flor Sci 41(1):12

Tilman D (1987) The importance of mechanisms of interspecific competition. Am Nat 129:769-774

Umminger BL (1972) Physiological studies on the supercooled killifish (Fundulus heteroclitus). IV. Carbohydrate metabolism in hypophysectomized killifish at subzero temperatures. J Exp Zool 181:217-222

Weatherly AH (1972) Growth and ecology of fish populations. Academic Press, New York

Weber JM, Kramer DL (1983) Effects of hypoxia and surface access on growth, mortality, and behavior of juvenile guppies Poecilia reticulata. Can J Fish Aquat Sci 40:1583-1588

Weisberg SB (1986) Competition and coexistence among four estuarine species of Fundulus. Am Zool 26:249-257

Whoriskey FG, Fitzgerald GJ (1987) Intraspecific competition in sticklebacks (Gasterosteidae: Pisces): does mother nature concur? J Anim Ecol 56:939-947

Whoriskey FG, Gaudreault A, Martel N, Campeau S, Fitzgerald GJ (1985) The activity budget and behavior pattern of female threespine sticklebacks, Gasterosteus aculeatus (L.). Nat Can (Rev Ecol Syst) 112:113-118

Winemiller KO (1989) Ontogenetic diet shifts and resource partitioning among piscivorous fishes in the Venezuelan llanos. Environ Biol Fish 26:177-199

Wooton RJ (1985) Effects of food and density on the reproductive biology of the threespine stickleback with a hypothesis on population limitation in sticklebacks. Behaviour 93: 101-111

Zar JH (1996) Biostatistical analysis, 3rd edn. Prentice Hall, Upper Saddle River, NJ

Zaret TM, Rand AS (1971) Competition in tropical stream fishes: support for the competitive exclusion principle. Ecology 52:336-342

Submitted: June 2, 1999; Accepted: May 16, 2000

Proofs received from author(s): November 8, 2000 